\title{
ANOMALY KEPENTINGAN ELIT DALAM KEBIJAKAN PUBLIC PRIVAT PARTNERSHIP (PPP) DI KOTA PEKANBARU
}

\author{
Alexsader Yandra, Bunga Chintia Utami \\ Universitas Lancang Kuning \\ e-mail: alexsy@unilak.ac.id
}

\begin{abstract}
Regional Regulation No. 8 of 2018 concerning waste management with a partnership between the Pekanbaru City Government and the private sector, better known as the Public Private Partnership Policy (PPP) is full of problems. Termination of employment contract and training employees because it is not in accordance with the contract for failure of policy implementation. Carry out qualitative research with data publication techniques, literature studies and in-depth interviews. So the decision that the PPP Pemko Pekanbaru policy involving the private sector, namely PT. MIG in managing waste in the city of Pekanbaru does not run smoothly or effectively. The failure of the Pekanbaru City Government in a partnership pattern with the private sector caused by anomalies in the benefits of the political elite in interpreting policies.
\end{abstract}

Keywords: Public Policy, Public Private Partnership

Peraturan Daerah No 8 tahun 2018 tentang pengelolaan sampah dengan pola kemitraan antara Pemerintah Kota Pekanbaru dengan private sector atau lebih dikenal dengan istilah Kebijakan Public Private Partnership (PPP) sarat akan masalah. Pemutusan kontrak sepihak dan mogoknya petugas sampah karena tidak dibayar sesuai kontrak berimplikasi kepada gagalnya implementasi kebijakan. Melalui pendekatan penelitian kualitatif dengan teknik pengumpulan data secara observasi, studi literatur dan wawancara mendalam. Maka hasilnya menunjukkan bahwa kebijakan PPP Pemko Pekanbaru yang melibatkan private sector yaitu PT. MIG dalam pengelolaan sampah di Kota Pekanbaru tidak berjalan lancar atau inefektif. Kegagalan Pemerintah kota Pekanbaru dalam pola kemitraan dengan private sector disebabkan oleh anomaly kepentingan elit politik dalam mengintrepretasikan kebijakan.

Kata Kunci : Kebijakan Publik, Publik Private Partnership

\section{PENDAHULUAN}

Kebijakan negara memilih Public Private Partnership (PPP) diantaranya seperti Amerika bertujuan untuk meningkatkan efisiensi operasional; Inggris bertujuan meningkatkan kompetisi; Korea selatan untuk mengakses dan mengembangkan teknologi baru; India untuk menciptakan kesempatan lapangan kerja; Afrika selatan untuk membuka investasi dan Filipina sebagai salah satu negara ASEAN bertujuan untuk menciptakan transparansi dalam pengadaan barang dan Jasa (Parente, 2006). Kebijakan PPP dianggap sebagai salah satu jalan keluar terhadap persoalan pembangunan yang ada. Namun seperti yang diungkapkan oleh Sharma \& Bindal (2014) bahwa dalam perjalanannya, kebijakan PPP bukanlah menjadi sebuah solusi tetapi menjadi persoalan baru yang dihadapi oleh Pemerintah. Prakteknya persoalan bahkan muncul ketika tahap awal kebijakan tersebut akan dilakukan seperti mendesain kontrak antara pemerintah dengan mitra yang bermasalah, hingga ekspektasi yang tidak realistis dari kebijakan PPP itu sendiri. 
Indonesia mengadopsi kebijakan PPP juga tak luput dari persoalan ketika mengimplementasikannya. Pemerintah mengatur mengenai pola kemitraan (PPP) antara pemerintah dengan sektor swasta melalui Perpres nomor 67 tahun 2005. Dan salah satu bidang yang dapat dilakukan dengan pola kemitraan adalah tentang pengelolaan sampah. Pengelolaan sampah di Indonesia diatur dengan Undang-undang Nomor 18 Tahun 2008. Kebijakan yang dibuat di tingkat pusat dilaksanakan oleh setiap Pemerintah Daerah kabupaten dengan mengeluarkan Peraturan Daerah. Pekanbaru sebagai salah satu kota yang ada di Provinsi Riau mengeluarkan Perda nomor 8 tahun 2014 tentang pengelolaan sampah. Sampah dikelola oleh penyelenggara pengelolaan sampah berupa Dinas, BUMD, Koperasi, Swasta dan kelompok masyarakat (Perda Nomor 8 Tahun 2014).

Penanganan sampah di Kota Pekanbaru untuk beberapa wilayah yaitu Kecamatan Marpoyan Damai, Senapelan, Sukajadi, Tampan, Sail, Pekanbaru Kota, Payung Sekaki dan Lima Puluh melakukan kemitraan dengan Pihak ketiga (swasta) dalam hal ini PT. Multi Inti Guna (MIG) menggunakan APBD 2015 dengan nilai kontrak 53 Miliar Rupiah. Sesuai dengan Perda nomor 8 tahun 2014 pasal 11 yang menyebutkan bahwa dalam pengelolaan sampah, Pemerintah Daerah dapat melakukan kemitraan dengan pihak Swasta. Sebaliknya permasalahan muncul pada bulan April 2016, gaji pegawai di bawah PT. MIG belum dibayarkan oleh PT. MIG. Akibatnya Pemko Pekanbaru melalui Dinas Kebersihan dan Pertamanan (DKP) melakukan pemutusan kontrak dengan PT. MIG dengan nomor surat 232/DKP/VI/2016 pada 15 Juni 2016. Dampaknya sampah menumpuk di delapan (8) wilayah yang menjadi area kontrak. Isu yang berkembang yaitu jumlah tonase sampah yang dilakukan oleh PT. Sucofindo yang menyebutkan bahwa jumlah sampah yang dihasilkan oleh Kota pekanbaru 610 Ton/hari. Tetapi Menurut pihak PT. MIG, Jumlah sampah jauh lebih kecil dari jumlah yang disebutkan. Sehingga PT. MIG mengalami kerugian. Maka dalam hal ini perlu dilihat kembali volume/ jumlah sampah yang menjadi objek dari kebijakan ini (Kontrak PPP antara Pemko Pekanbaru dan PT. MIG). Kedua Pemutusan sepihak oleh Pemko Pekanbaru terkait pengelolaan sampah yang dilakukan oleh PT. MIG. Pemko Pekanbaru menilai bahwa PT. MIG telah melakukan penyalahgunaan kontrak, sedangkan pihak PT. MIG menilai bahwa Pemko Pekanbaru telah menyalahi kebijakan pola kemitraan dengan melakukan pemutusan secara sepihak.

Perpres Nomor 54 Tahun 2010 menjelaskan pemutusan kontrak sepatutnya didahului dengan peringatan pertama, peringatan kedua hingga peringatan ketiga yang di masing-masing tindakan diikuti dengan show cause meeting. Sedangkan proses terakhir adalah test case yang akan menentukan sebuah penyedia lulus atau tidak dalam keberlanjutan kontrak. Dan PT. MIG mempermasalahkan tidak adanya tahapan-tahapan ini dilakukan. Bagi PT MIG realitas tersebut memberikan arah kebijakan PPP yang didominasi oleh elit dipemerintahan tanpa memperhatikan aspek-aspek penyelenggaran yang fair. Kegagalan kebijakan juga berdampak langsung kepada masyarakat, Oleh sebab itu perlu dilakukan kajian terkait anomaly kebijakan PPP antara Pemko Pekanbaru dan PT. MIG. Maka pembahasannya mendeskripsikan anomaly elit dalam implementasi kebijakan Public Private Partnership (PPP) antara Pemko Pekanbaru dengan PT. MIG dalam pengelolaan sampah serta faktor kegagalan kebijakan Public Private Partnership (PPP) di Kota Pekanbaru.

\section{Public Private Partnership (PPP)}

Parente (2006) menyebutkan bahwa Public Private partnership(PPP) yaitu

"an agreement or contract, between a public entity and a private party, under which : (a) private party undertakes government function for specified period of time, $(b)$ the private party receives compensation for performing the function, directly or indirectly, $(c)$ the private party is liable for the risks arising from performing the function and, $(d)$ the public facilities, land or other resources may be transferred or made available to the private party."

PPP adalah salah satu solusi yang ditawarkan ketika pembangunan tidak bisa dilakukan dengan berbagai alasan di suatu wilayah Negara atau daerah. Misalnya keterbatasan dana, sumber daya, sumber 
daya manusia dan lain sebagainya. Prinsip yang diatur dan dimunculkan dalam semangat PPP haruslah selalu berorientasi dan ditujukan semata-mata untuk kepentingan Publik.

\section{Kebijakan Publik}

Menurut Thomas R. Dye (1992) yang dikutip oleh Anggara (2014 : 35) menterjemahkan kebijakan publik sebagai "Whattever the government choose to do or not to do". Defenisi ini mengindikasikan bahwa ketika pemerintah tidak melakukan sesuatu atas persoalan publik yang muncul itu disebut sebagai kebijakan publik. Karena "tindakan" pemerintah bisa diartikan melakukan atau tidak melakukan.

Sedangkan David Easton mendefenisikan kebijakan publik sebagai pengalokasian nilai-nilai secara sah kepada seluruh anggota masyarakat (Anggara, 2014:35). Dalam pelaksanaannya, proses kebijakan publik menurut Dunn (1995) terdiri atas beberapa tahapan. Yaitu : Penyusunan Agenda, Formulasi kebijakan, Adopsi/legitimasi kebijakan, Penilaian/ evaluasi kebijakan Winarno (2008), menyebutkan bahwa evaluasi kebijakan adalah kegiatan yang menyangkut estimasi atau penilaian kebijakan yang mencakup substansi, implementasi, dan dampak (Anggara, 2014:121).

\section{METODE}

Penelitian ini menggunakan pendekatan kualitatif, agar menjelaskan kegagalan kebijakan Public Private partnership (PPP) dalam pengelolaan sampah. Penelitian ini dilakukan di Kota pekanbaru. Adapun data Primer yaitu orang-orang yang terkait dalam lingkaran dan lingkungan kebijakan Public private partnership (PPP) antara Pemko Pekanbaru dengan PT. MIG. Selanjutnya data sekundernya yaitu data yang diperoleh dari peraturan-peraturan baik itu Undang-undang maupun hingga turunannya, literatur yang terkait Kebijakan PPP, media cetak, ataupun media elektronik yang berkaitan dengan kebijakan PPP. Teknik pengumpulan data yang digunakan dalam penelitian ini yaitu Observasi, Studi Kepustakaan, Wawancara. Analisa data dilakukan dengan menggunakan teknik yang dikemukakan oleh Miles dan Huberman yang dikutip oleh Emzir (2010), yaitu reduksi data, penyajian data dan penarikan kesimpulan. Selanjutnya data dianalisasi dengan intrepetasi pola single case, sehingga data yang dihasilkan dapat mencerminkan permasalahan yang terjadi terkait faktor apakah yang menyebabkan kebijakan PPP di Kota Pekanbaru dalam pengelolaan sampah tidak berjalan.

\section{HASIL DAN PEMBAHASAN}

\section{Kebijakan Public Private Partnership (PPP) dalam Pengelolaan Sampah di Kota Pekanbaru}

Undang-Undang Republik Indonesia Nomor 18 Tahun 2008 tentang Pengelolaan Sampah pasal 5 menjelaskan bahwa pemerintah dan pemerintahan daerah bertugas menjamin terselenggaranya pengelolaan sampah yang baik dan berwawasan lingkungan. Amanat Peraturan Pemerintah Nomor 38 Tahun 2007 tentang Pembagian Urusan Pemerintahan antara Pusat,Pemerintahan daerah Propinsi, dan Pemerintahan Daerah Kabupaten/Kota, pada dasarnya fungsi utama yang wajib dilaksanakan oleh Pemerintah daerah adalah menyelenggarakan urusan wajib yang pada hakekatnya merupakan bagian dari pelayanan publik. Maka pelayanan publik untuk kelancaran penyelenggaraan roda pemerintahan dan pelaksanaan pembangunan nasional dan otonomi daerah sangat ditentukan oleh kemampuan penyelenggara pembangunan serta pendayagunaan aparatur Negara yang berkualitas, efektif, efisien dan berwibawa yang dalam pelaksanaan pembangunan selalu dihadapkan dengan permasalahan-permasalahan seperti masalah sosial,budaya, ekonomi, keamanan dan ketertiban umum. 
Permasalahan mendasar pada Pemerintah Kota Pekanbaru adalah penanggulangan dan pengelolaan sampah yang dihasilkan masyarakat baik individu maupun kelompok. Pertambahan penduduk dan perubahan pola konsumsi masyarakat menimbulkan bertambahnya volume, jenis dan karakteristik sampah yang semakin beragam. Pengelolaan sampah selama ini belum sesuai dengan metode dan teknik pengelolaan sampah yang berwawasan lingkungan sehingga menimbulkan dampak negatif terhadap kesehatan masyarakat dan lingkungan Dengan padatnya jumlah penduduk Kota Pekanbaru yakni sekitar 1.021.710 jiwa dan perubahan pola konsumsi masyarakat dapat menimbulkan bertambahnya volume, jenis dan karakteristik sampah yang semakin beragam, permasalahan sampah semakin komplek dan perlu dikelola secara profesional berdasarkan UU RI Nomor 08 Tahun 2008 dan Peraturan Daerah Kota Pekanbaru Nomor 8 Tahun 2014 tentang Pengelolaan Persampahan. Diamanatkan bahwa pengelolaan kebersihan merupakan tanggung jawab Pemerintah Daerah, dalam hal ini dilaksanakan oleh Dinas Kebersihan dan Pertamanan Kota Pekanbaru serta SKPD lainnya.

Proses formulasi kebijakan publik private partenership terkait peraturan daerah 8 Tahun 2014 tentang Pengelolaan Persampahan dalam perumusannya belum melibatkan partisipasi aktif masyarakat, implikasinya masyarakat pekanbaru belum menjalankan fungsi kontrol terhadap proses kebijakan dan sanksi dari perda tersebut. Output dari kebijakan PPP tentang peraturan daerah 8 Tahun 2014 kota pekanbaru melahirkan kesepakatan antara pemerintah dengan PT. MIG yang tertuang dalam kontrak, tetapi dalam kontrak tersebut tidak tertuang sanksi dari kesepakatan dari kedua belah pihak intrepertasinya perda ini sangat minim akan memperhatikan dampak yang akan timbul dikemudian hari terkait kontrak yang disepakati. Kebijakan PPP di Kota Pekanbaru berorientasi kepada projek yang berkaitan untung dan rugi, dimana kedua belah pihak antara pemerintah kota dengan pihak PT. MIG tidak ingin disalahkan atas kondisi penumpukan sampah yang terjadi pada pertengahan tahun 2016 tersebut.

Orientasi kebijakan PPP sangat sarat akan berbagai kepentingan politik dari berbagai pihak sehingga kebijakan ini menimbulkan distorsi orientasi. Oriantasi projeklah yang menjadi kepentingan dominan dari aktor-aktor yang terlibat dalam kebijakan ini. Dimana sistem dan mekanisme implementasi kebijakan sudah tidak lagi menjadi acuan ataupun pertimbangan dalam pola hubungan kemitraan antara pemerintah kota pekanbaru dengan PT.MIG.

\section{Penyusunan Agenda Kebijakan Dalam Merespon Isu Sampah}

Fase yang sangat strategis dalam tahapan proses kebijakan. Karena pada fase inilah, berbagai isu berkompetisi untuk menjadi masalah publik dan berhak mendapatkan sumber daya yang lebih dari isu publik lainnya. Penelitian ini menjadikan jumlah penduduk sebagai isu yang semakin hari semakin meningkat akan memberikan ancaman produksi sampah yang semakin besar pula, dan itu akan membuat kesulitan dalam mengendalikan pelaksanaan pengelolaan penumpukan sampah. Bertambahnya jumlah penduduk sudah tentu beriringan dengan bertambahnya pula produksi sampah di Kota Pekanbaru dan kurangnya pengetahuan masyarakat akan pentingnya kebersihan juga menjadi penyebab dari masalah sampah yang menghinggapi Kota Pekanbaru hari ini. Tentunya pertumbuhan penduduk sangat mengancam dalam pengendalian kebersihan jika tidak diiringi dengan support dari kelompok civil society. Kota Pekanbaru yang memiliki populasi penduduk yang bergerak sangat cepat menyebabkan Pemerintah harus berusaha mengatasi jumlah penumpukan sampah yang didominasi dengan sampah rumah tangga.

Rendahnya pengetahuan masyarakat terhadap pentingnya kebersihan menjadi salah satu isu yang harus direspon dengan cepat karena akan berdampak terhadap partisipasi mereka terhadap kebersihan. Hal tersebut diungkapkan oleh Kasi Kebersihan Lingkungan Dinas Kebersihan dan Pertamanan Kota Pekanbaru, dukungan dan peran aktif masyarakat sangat diharapkan dan apabila masyarakat kurang aktif maka masalah penumpukan sampah tidak dapat tertangani dengan maksimal dan baik. Kurang aktifnya peran masyarakat dalam mengendalikan penumpukan sampah di lingkungan 
mereka sendiri. Menurutnya, masyarakat membuang sampah secara estafet dan tidak sesuai dengan waktu yang ditentukan.

Kurangnya kesadaran masyarakat terhadap aturan yang sudah dibuat terkait jam buang sampah, menyebabkan mereka masih tidak perduli akan aturan yang telah ada. Hal ini dikarenakan lagi-lagi petugas pengangkutlah yang bertugas mengangkut sampah hanya sesekali mengakut sampah yang ada di lingkungan masyarakat. Masyarakat tidak mengetahui bahwa pengelolaan penumpukan sampah saat ini dikelola oleh pemerintah dan juga swasta. Mereka menilai bahwa dengan adanya kerjasama ini, tidak ada perbedaan sama sekali dengan sebelum adanya kerjasama ini dilakukan. Partisipasi masyarakat artinya keikutsertaan dan kepedulian masyarakat dalam pengelolaan penumpukan sampah oleh Dinas Kebersihan dan Pertamanan serta PT. Multi Inti Guna dengan adanya layanan pengaduan masyarakat dapat membantu mengatasi rumitnya permasalahan penumpukan sampah. Sangat diharapkan juga peran aktif masyarakat dalam pengendalian penumpukan sampah meskipun dari hal terkecil dengan membuang sampah sesuai dengan waktu yang telah ditentukan demi mewujudkan Kota Pekanbaru yang bersih dan sehat. Bentuk lain dari partisipasi masyarakat juga dapat berupa kesadaran masyarakat itu sendiri untuk mematuhi dan memahami peraturan yang ada.

Dalam pengimplementasian Perda nomor 8 tahun 2014 tentang pengelolaan sampah harus melalui proses yang transparan antara pemerintah kota dengan private sector yaitu PT. MIG dan keterlibatan partisipatif aktif dari kelompok masyarakat. Akan tetapi Perda ini tidak dapat dilaksanakan atau direalisasikan karena mengalami berbagai kendala politik dan administrasi seperti kontrak kebijakan. Berbagai persolan tersebut di analisis melalui teori Grindle tentang implementasi kebijakan publik yang di pengaruhi oleh banyaknya kepentingan, kekuasaan kepentingan dan strategi aktor yang terlibat sedangkan (Riant Nugroho,2007:78).

\section{Anomaly Kepentingan Elit dalam Implementasi Kebijakan PPP}

Kebijakan publik Perda No 8 tahun 2014 awalnya merupakan sebuah jawaban dari permasalahan sampah di Kota Pekanbaru rentang waktu 209-2013, dimana volume sampah samakin meningkat pertahunnya yang menimbulkan penumpukan dan lingkungan kotor. Akan tetapi kebijakan tersebut memiliki permasalahan dalam implementasi kebijakan, yang awalnya diharapkan memberikan solusi terhadap permasalahan sampah namun malah menimbulkan paradok baru. Terjadinya malfungsi dari kebijakan PPP Perda No 8 tahun 2014 terlihat dari orientasi kepentingan aktor atau elit pelaksana kebijakan yang cendrung keliru, dimana pengelolaan yang seharusnya beorientasi kepada bisnis sampah (core buisnies) namun yang terjadi hanya mengalihfungsikan ke Private sector untuk pengangkutan sampah. Orientasi bisnis masih dipahami elit pembuat kebijakan dan Pelaksana Kebijakan yaitu PT.MIG dalam makna yang singkat tetapi sebaliknya tidak dipahami dalam makna yang luas yaitu pengelolaan dan pemanfaatan sampah untuk kepentingan ekonomi.

Kepentingan masyarakat untuk memperoleh lingkungan yang bersih dan nyaman terpengaruhi dengan pelaksanaan PPP antara pemerintah dan PT MIG. Masyarakat berhak menerima pelayanan publik yang baik dan berkualitas. Namun kondisi saat itu, menyebabkan kepuasan masyarakat pekanbaru rendah sehingga muncul gugatan dari masyarakat ke pemerintah kota dan PT MIG terkait pengelolaan sampah yang belum optimal. PT MIG menangani pengelolaan sampah di 8 kecamatan yaitu Marpoyan Damai, Senapelan, Sukajadi, Tampan, Sail, Pekanbaru Kota, Payung Sekaki, dan Lima Puluh. Sehingga masyarakat dari 8 kecamatan melayangkan gugatan melalui Lembaga Bantuan Hukum (LBH). Masyarakat merasa dirugikan dengan adanya pelanggaran Undang-undang nomor 18 tahun 2008 tentang Pengelolaan sampah. Gugatan yang diajukan atas kerugian materil dan nonmateril sebesar 53 Milyar kepada masing-masing pihak baik pemerintah maupun PT MIG.

Lingkup kebijakan terlihat adanya tiga unsur yang berkepentingan akan kebijakan PPP ini diantaranya Pemko Pekanbaru, Private Sektor (PT.MIG) dan Masyarakat. Ketiganya tentu bahagian yang 
tidak terpisahkan dari aspek kebijakan, namun sebaliknya ketiganya tidak memiliki persepsi yang sama akan kebijakan ini sehingga kebijakan ini terdistorsi oleh tujuan ketiga unsur masing-masing.

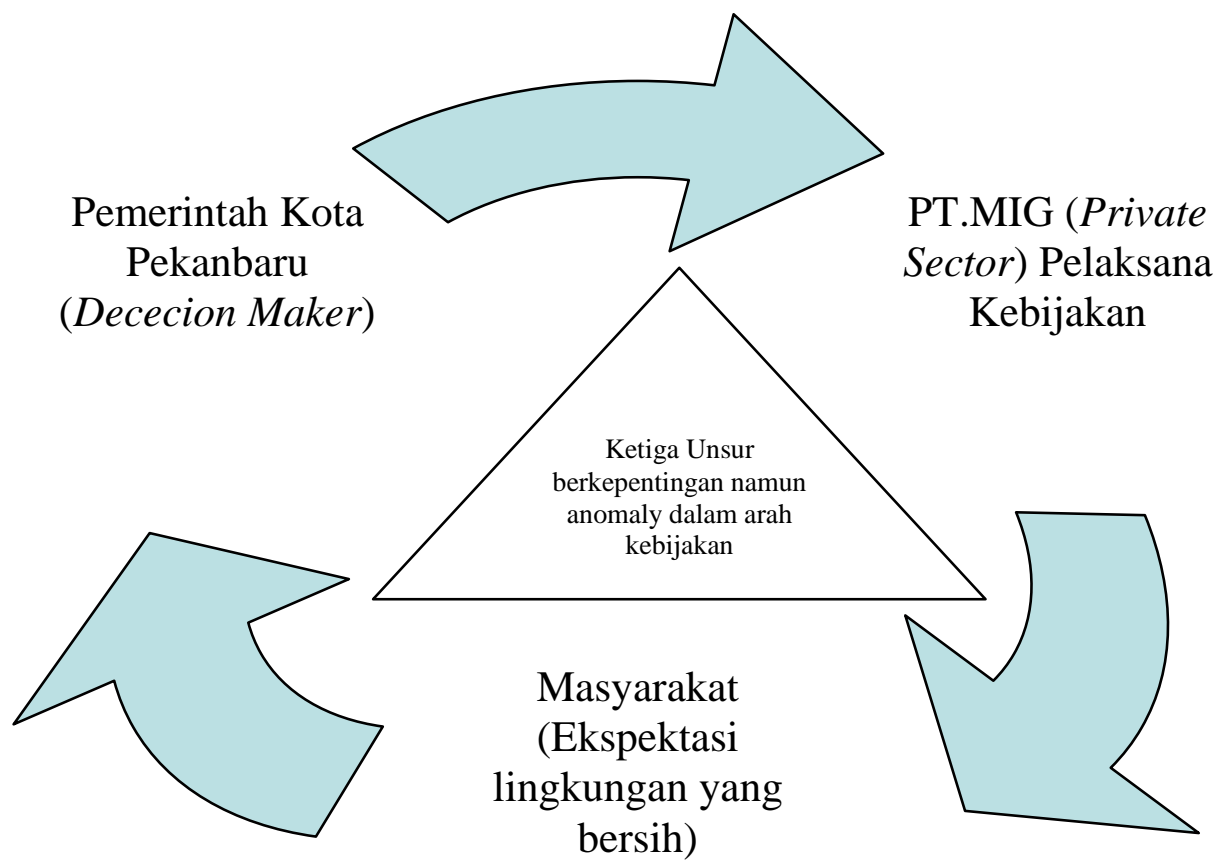

Sisi lainnya, PT MIG juga berperan sebagai pihak kepentingan yang melaksanakan kebijakan. Nilai kontrak antara PT MIG dan Pemerintah Kota pekanbaru sebesar 51 Milyar tidak dibayarkan secara keseluruhan tetapi bertahap. Terhitung hingga bulan juni 2016, PT MIG menerima pembayaran 9,7 milyar dalam kurun waktu kerja yang telah setengah tahun seharusnya pembayaran juga dilakukan setengah yaitu 2 milyar tetapi karena kondisi penganggaran daerah yang masih blum tepat waktu dan terkendala pendanaan prioritas lainnya maka pembiayan terhadap PT MIG tidak terlaksana sebagaimana mestinya.

Namun keterlambatan pembayaran tidak bisa diterima oleh PT MIG yang berimbas pada keterlambatan pembayaran honor dari Tenaga Harian Lepas (THL). Keterlambatan pembayaran honor THL menyebabkan mogok kerja yang dilakukan THL dan berimbas pada penumpukan sampah diberbagai titik TPS dan ruas jalan. Pemutusan kerjasama secara sepihak oleh DKP terhadap PT MIG yang telah melakukan gugatan atas pemutusan kerjasama sepihak tersebut dimemenangkan oleh PT.MIG dengan ganti rugi sebesar Rp. 12.771.343.138 terhadap DKP.

\section{Karakteristik Lembaga Dan Penguasa}

Kesepahaman antara PT MIG dan DKP pada awal terkait jumlah sampah yang harus dipenuhi sebesar 610 ton ternyata tidak sejalan hingga proses akhir pelaksanaan kerjasama. PT MIG mengajukan keberatan atas jumlah sampah perhari ketika kondisi dilapangan tidak terpenuhi dan mengajukan gugatan terhadap fisibliity study yang dilakukan oleh DKP diangap tidak sesuai dengan kondisi sebenarnya. Seharunya sebelum hal tersebut terjadi PT MIG juga harus melakukan pengkajian tersendiri untuk menemukan jumlah sampah perhari sebenarnya atau seharusnya sebelum kontrak ditetapkan ada penghitungan bersama terhadap target sampah perhari. 
Setiap kesepakatan harus dapat terukur baik secara kualitatif maupun secara kuantitatif, sehingga kontrak yang akan menjadi dasar dari kegiatan ataupun implementasi kebijakan dapat mencakup segala aspek yang akan terjadi dikemudian hari seperti terjadinya turbulensi kebijakan. Namun Turbulensi kebijakan PPP dalam pengelolaan sampah di Kota Pekanbaru ini berawal dari kebijakan yang tidak tepat sasaran, tidak sesuai target dan lingkungan kebijakan didominasi oleh factor politik, orientasi dan teknis pelaksanaan kebijakan. Oleh karena itu turbulensi kebijakan merupakan dinamika kebijakan yang disebabkan oleh distorsi orientasi dan anomaly elit penyelenggara yang kesepakatan dalam kontrak kebijakan didominasi oleh peran pemerintah sebagai pengambil kebijakan.

\section{Kepatuhan serta daya tanggap pelaksana}

Kepatuhan DKP dan PT MIG terhadap pelaksanaan kerjasama dianggap kurang maksimal. Kedua belah pihak dianggap kurang oprimal dalam melaksanakan kewajiban masing-masing. Pemerintah melakukan keterlambatan pembayaran dan PT MIG tidak memenuhi target kontrak untuk jumlah sampah perhari. Berbagai permasalahan yang timbul menyebabkan Pemutusan kontrak . Kepatuhan kedua belah pihak atas pemutusan kontrak telah sesuai dengan amanat Peraturan Presiden Nomor 4 Tahun 2015. Hasil pemutusan tersebut maka PT MIG harus melakukan penyelesaian pembayaran THL sesuai hasil kerja yang belum diayarkan dan Pemerintah melalui DKP harus mengambil alih kembali THL yang di putus hubungan kerja dengan PT MIG menjadi THL DKP kembali.

Respon lainnya yang dilakukan pemerintah kota Pekanbaru ketika kontrak kerjasama tidak berjalan sebagaimana mestinya adalah pengalihan anggran dan tenaga kerja dari 4 kecamatan di Kota Pekanbaru. Pengalihan ini bertujuan mengurangi beban kerja pengangkutan sampah yang seharusnya menjadi tanggungan DKP. Keterbatasan sarana angkut DKP dibantu oleh armada angkut dari kecamatan Sail, Rumbai, Rumbai Pesisir dan Tenayan. Sehingga pada masa awal transisi pelaksanaan kebijakan kembali ke DKP menggunakan 33 armada angkutan sampah dan dibantu armada Dinas Cipta Karya dan Bina Marga

\section{KESIMPULAN}

Kebijakan publik private partnership (PPP) dalam pengelolaan sampah di Kota Pekanbaru sudah berjalan tetapi tidak maksimal dikarenakan adanya kendala pada proses agenda perumusan kebijakan beorientasi pada projek yang menyebabkan inefektifitas kebijakan PPP tersebut. Adapun faktor penghambat tersebut diantaranya Tempat Pembuangan Sampah (TPA) yang tidak efektif, Pertumbuhan Penduduk, Pengetahuan dan Partisipasi Masyarakat, Sumber Daya Manusia, Sarana dan Prasarana, Dana/Anggaran pemerintah yang tidak tepat dalam perencanaan. Perlu evaluasi terhadap kebijakan Publik Private Partnership (PPP) yaitu Peraturan Daerah Kota Pekanbaru Nomor 8 Tahun 2014 tentang Pengelolaan Persampahan. Diamanatkan bahwa pengelolaan kebersihan merupakan tanggung jawab Pemerintah Daerah, dalam hal ini dilaksanakan oleh Dinas Kebersihan dan Pertamanan Kota Pekanbaru serta SKPD lainnya perlu evaluasi manajemen kerja Pemerintah Kota Pekanbaru dengan Pihak Swasta dalam hal ini adalah PT. MIG.

\section{UCAPAN TERIMA KASIH}

Terima kasih kepada Kemenristek Dikti Direktorat Riset Dan Pengabdian Masyarakat (DPRM) atas bantuan dana dalam kegiatan penelitian ini sesuai kontrak penelitian tahun anggaran 2018 nomor : 007/kontrak-penelitian/K10/KM/2018. 


\section{DAFTAR PUSTAKA}

[1].Anggara, Sahya. (2014). Kebijakan Publik. Pustaka Setia: Bandung

[2].Ariesto Hadi Sutopo dan Adrianus Arief, (2010). Terampil Mengolah Data Kualitatif Dengan NVIVO. Prenada Media Group : Jakarta.

[3].Creswell, J. W., \& Clark, V. L. P. (2007). Designing and conducting mixed methods research. Wiley online Publication

[4].Dailiati, S., \& Utami, B. C. (2018, May). Cleanliness Policy Implementation: Evaluating Retribution Model to Rise Public Satisfaction. In IOP Conference Series: Earth and Environmental Science (Vol. 156, No. 1, p. 012011). IOP Publishing.

[5].Djunedi, Praptono. (2007). Implementasi Public-Private Partnership dan Dampaknya ke APBN. Majalah Warta Anggaran Edisi 6 Tahun 2007, Direktorat Jenderal Anggaran

[6].Emzir.2010.Metodologi Penelitian Kualitatif:Analisis Data.Jakarta: Rajawali Pers Rahmat, P. S. (2009). Penelitian kualitatif. Equilibrium, 5(9), 1-8.

[7].Parente, William J., "Public Private Partnerships" dalam Workshop on "Fundamental Principles and Techniques for Effective Public Private Partnerships in Indonesia”, Jakarta, 2006

[8].Peraturan Presiden Nomor 67 Tahun 2005 tentang Kerjasama Pemerintah dan Badan Usaha dalam Penyediaan Infrastruktur

[9].Perda Kota Pekanbaru nomor 8 tahun 2014 tentang pengelolaan sampah

[10].Sharma\& Bindal. (2014). Public Private Partnership. International Journal of Research (IJR) Vol-1, Issue-7, August 2014

[11].Yandra, Alexsander. M.Si, Mei 2014. Jurnal Avicenna: Kendala Dalam Implementasi Kebijakan Publik. Universitas Abdurrab. Volume 4, Nomor 1, ISSN:2089-2268, Fax 0761-859839, 20 Mei 2016 